\title{
Optimization of the technology of clonal micro- propagation of cherry varieties and clonal rootstocks at the initial stages of in vitro cultivation
}

\author{
O.V. Ostrikova*, I.E. Fedotova, E.L. Kharkhardina, and V.V. Shakhov, \\ FSBEI HE "OSU n.a. I.S. Turgenev", Orel, Russia
}

\begin{abstract}
The article presents the results of studying some components of the in vitro technology of clonal rootstocks and common cherry varieties, which allow to increase the efficiency of its application to the tested cherry varieties and clonal rootstocks. Differences in the viability and intensity of the development of clonal cherry rootstocks and varieties explants depending on the timing of their introduction into the crop, the characteristics of genotypes and the composition of nutrient media were established. The influence of nutrient medium composition, content and ratio of growth regulators and genotype in it on the multiplication coefficient of cherry varieties and clonal rootstocks was revealed. The optimal calendar dates for the introduction of cherry varieties and clonal rootstocks explants into the crop in vitro for the autumn-winter-spring period are established. The optimal composition of the culture medium for the initial stages of clonal micropropagation is established. The reproductive potential of some clonal rootstocks and cherry varieties in crop in vitro was revealed.
\end{abstract}

\section{Introduction}

Common cherry (P. cerasus L. or C. vulgaris Mill.) is one of the most popular stone fruit crops. Its fruits have a pleasant taste, have a high concentration of antioxidants and vitamins ( $\mathrm{C}, \mathrm{P}, \mathrm{B}_{2}, \mathrm{~B}_{9}$, etc.), macro- and microelements, biologically active substances that prevent the development of many diseases [1].

On the territory of Russia, the industrial culture of common cherry has mainly developed in the middle zone of fruit growing (Central Chernozem, Central, North-Western (western regions), Lower Volga (except for the Astrakhan region), Middle Volga regions). Despite the fact that more than 80 common cherry varieties are included in the State Register for the middle zone of fruit growing, this stone fruit crop has practically lost its industrial significance here and is cultivated to a greater extent in amateur gardening $[1,2]$.

One of the reasons for this situation in the Central region of Russia is the lack of highquality virus-free planting material of this crop. The problem of obtaining virus-free planting material in sufficient quantities for laying mother and industrial cherry plantations

*Corresponding author: ostrikova_ov@mail.ru 
can be solved by the technology of clonal micro-propagation, aimed both at mass replication of root-related seedlings of valuable cherry varieties, and at the reproduction of its clonal rootstocks $[3,4,5,6]$.

Nevertheless, there are very few commercial laboratories in our country that successfully use biotechnological techniques to propagate valuable cherry varieties and rootstocks. This is due to the many difficulties and problems that arise at each stage of clonal micropropagation and, ultimately, affect its effectiveness.

Thus, at the first stage of cultivation, there is a problem of choosing the optimal calendar dates for the introduction of cherry explants into the crop in vitro. There is still no clear answer to this question among research scientists [7, 8]. The effectiveness of clonal micropropagation at this stage is largely determined by the composition of nutrient media and the content of growth regulators in them [9, 10]. The composition of the culture medium affects the viability and intensity of the development of cherry micro-plants at the second stage of clonal micro-propagation (at proliferation stage). At the same time, one of the main problems of the second stage is the insufficient multiplication factor of cultivated cherry explants, which is primarily determined by the composition and ratio of growth regulators in the culture medium $[11,12]$. It should also be noted that the effectiveness of the stages of clonal cherry micro-propagation under in vitro conditions is genetically determined, i.e. the cultivating methods, technologies and procedures are variety-specific and require an individual approach in the development and selection of specific components.

Therefore, the purpose of our work was to identify the optimal components of clonal micro-propagation at its initial stages, which allow to increase the effectiveness of this technology in relation to some varieties and clonal rootstocks of common cherry.

\section{Materials and methods}

Place of research - Laboratory of Biotechnology of the FSBEI HE Oryol State University n.a. I.S. Turgenev in 2017-2020. Generally accepted methods were used for explant cultivation $[13,14,15]$.

The research was conducted in the following areas: the study of different terms of introduction into the crop in vitro(autumn-spring), the study of the growth and development of explants on nutrient media different by composition and content of growth hormones (Murashige and Skoog medium (MS) and Experimental (EX), modified MS with an excellent content of calcium, ammonium nitrate and potassium).

The content of growth regulators in different media is shown in Table 1.

Table 1. Content of growth regulators in various nutrient media at the initial stages of clonal micropropagation

\begin{tabular}{|c|c|c|c|c|}
\hline \multirow{2}{*}{ Growth regulators } & \multicolumn{4}{|c|}{ Concentration of growth regulators in nutrient media, mg/I } \\
\cline { 2 - 5 } & MS-I & MS-II & EX-I & EX-II \\
\hline 6-BAP & 2.00 & 1.00 & 1.50 & 1.50 \\
\hline GA & 0.00 & 0.50 & 0.50 & 0.50 \\
\hline IBA & 0.00 & 0.50 & 1.00 & 0.50 \\
\hline
\end{tabular}

The objects of research are common cherry varieties (Podarok Uchitlyam, Livenskaya, Rovesnitsa, Turgenevka) and its clonal rootstocks (V 2-180, Rubin, Izmailovsky).

The initial explants for in vitro cultivation were the meristems of the apical and lateral vegetative buds of annual shoots of common cherry varieties and rootstocks. 
A 3\% solution of Lysoformin was used as the main sterilizing agent. For uniform rotation of objects during sterilization, a magnetic stirrer was used.

To assess the cultivation effectiveness at the stages of introduction into the crop in vitro and proliferation, such indicators as: viability, intensity of development (length of microshoots), reproduction coefficient were used.

\section{Results and discussion}

Studying the influence of calendar dates of introduction into the crop in vitro on their viability, differences between the tested genotypes were established (Table 2).

Table 2. Influence of calendar dates of introduction into the crop in vitro on the viability of explants of common cherry varieties, on average for $2017-2020, \%$.

\begin{tabular}{|c|c|c|c|c|c|}
\hline \multirow{2}{*}{ Genotype name } & \multicolumn{5}{|c|}{ Explant viability, \% } \\
\cline { 2 - 6 } & October & November & January & February & March \\
\hline $\begin{array}{c}\text { Podarok } \\
\text { Uchitelyam }\end{array}$ & 58.00 & 61.29 & 48.89 & 72.25 & 50.00 \\
\hline Livenskaya & 54.60 & 35.63 & 70.51 & 72.62 & 66.90 \\
\hline Turgenevka & 61.25 & 36.25 & 75.75 & 79.75 & 78.12 \\
\hline Rovesnitsa & 75.50 & 39.65 & 64.25 & 57.33 & 65.00 \\
\hline V2-180 & 90.75 & 51.25 & 43.10 & 61.25 & 80.91 \\
\hline Izmailovsky & 97.00 & 76.50 & 50.45 & 68.09 & 74.11 \\
\hline Rubin & 76.38 & 50.38 & 39.40 & 68.85 & 70.53 \\
\hline $\begin{array}{c}\text { Average for } \\
\text { genotype }\end{array}$ & $\mathbf{7 3 . 3 5}$ & $\mathbf{5 0 . 1 4}$ & $\mathbf{5 6 . 0 5}$ & $\mathbf{6 8 . 5 9}$ & $\mathbf{6 9 . 3 7}$ \\
\hline LSD 05 & 5.46 & 3.27 & 3.16 & 2.61 & 3.76 \\
\hline
\end{tabular}

The introduced cherry explants showed greater viability when cultivated in vitro in October (73.35\%), February (68.59\%), and March (69.37\%). Explants of all clonal rootstocks performed better when they were introduced in October, and in most of the studied common cherry varieties - in February, and only in the Rovesnitsa variety, the greater viability of explants was noted when they were introduced in October. On the one hand, this indicates the variety-specific nature of the clonal micropropagation technology when choosing the dates of plant explant introduction into the crop in vitro. On the other hand, it indicates that explants isolated from the buds of annual cherry shoots, which either have not yet entered a state of deep dormancy (in October), or have already emerged from it and are in the stage of induced dormancy (in February - March), have the best survival rate in crop in vitro.

The results of studies of the effect of the time of introduction of clonal rootstocks and cherry varieties explants into the crop in vitro on the intensity of their development after a month of cultivation are presented in Table 3. It was found that the best intensity of microplants development was observed when they were introduced into the crop in vitro in March $(8.88 \mathrm{~mm})$. Only the cherry varieties Rovesnitsa and Podarok Uchitelyam showed the best intensity of explant development in February $(7.50 \mathrm{~mm})$ and January $(7.83 \mathrm{~mm})$, respectively. The worst months for the introduction of all cherry genotypes into the crop were October and November. On average, the development intensity of micro-plants introduced into the crop in vitro in these months was 4.28 and $4.82 \mathrm{~mm}$, respectively. Thus, despite some variety-specific intensity of cherry micro-plants development at different times of their introduction into the crop, it was found that common cherry explants that were obtained from the buds of annual shoots that were already in a state of induced dormancy developed better in the crop in vitro. 
Table 3. Dependence of development intensity of plant explants on the time of introduction into crop in vitro, on average for 2017-2020, $\mathrm{mm}$.

\begin{tabular}{|c|c|c|c|c|c|}
\hline \multirow{2}{*}{ Genotype name } & \multicolumn{5}{|c|}{ Micro-plants length, mm } \\
\cline { 2 - 6 } & October & November & January & February & March \\
\hline $\begin{array}{c}\text { Podarok } \\
\text { Uchitelyam }\end{array}$ & 4.78 & 6.57 & 6.60 & 7.50 & 7.25 \\
\hline Livenskaya & 3.58 & 4.63 & 4.95 & 6.00 & 7.50 \\
\hline Turgenevka & 4.00 & 4.42 & 6.00 & 6.05 & 7.50 \\
\hline Rovesnitsa & 3.08 & 6.65 & 7.83 & 5.45 & 6.00 \\
\hline V2-180 & 4.25 & 2.35 & 4.90 & 6.90 & 9.58 \\
\hline Izmailovsky & 5.10 & 4.30 & 5.55 & 6.99 & 10.69 \\
\hline Rubin & 5.20 & 4.80 & 6.05 & 8.15 & 13.63 \\
\hline $\begin{array}{c}\text { Average for } \\
\text { genotype }\end{array}$ & $\mathbf{4 . 2 8}$ & $\mathbf{4 . 8 2}$ & $\mathbf{5 . 9 8}$ & $\mathbf{6 . 7 2}$ & $\mathbf{8 . 8 8}$ \\
\hline LSD 05 & 0.29 & 0.33 & 0.45 & 0.52 & 0.93 \\
\hline
\end{tabular}

Analyzing the results obtained on the study of the dates of the explants introduction into the crop in vitro for viability, intensity of development, we came to the conclusion that the optimal time of introduction into the crop in vitro for the autumn-winter-spring period is February and March.

When studying the effect of the mineral composition of nutrient media and growth regulators on the effectiveness of the first stage of clonal micro-propagation, it was found that the explants of most of the studied common cherry genotypes have the best viability when cultivated on an Experimental medium (on average 76.23 \%) (Table 4). Most of them showed higher viability on the EX-II medium (78.81\% on average). The exception was the clonal rootstock Rubin, which demonstrated better viability on the MS-II medium (76.50\%).

Table 4. Dependence of cherry explants viability at the stage of introduction into the crop in vitro on the genotype and composition of the nutrient medium, on average for $2017-2020$., $\%$

\begin{tabular}{|c|c|c|c|c|c|}
\hline \multirow{2}{*}{ Genotype name } & \multicolumn{5}{|c|}{ Explant viability, \% } \\
\cline { 2 - 6 } & MS-I & MS-II & EX-I & EX-II & $\begin{array}{c}\text { Average for } \\
\text { genotype }\end{array}$ \\
\hline Livenskaya & 64.90 & 63.53 & 66.81 & 66.35 & 65.40 \\
\hline Podarok Uchitelyam & 65.90 & 66.14 & 81.25 & 74.90 & 72.05 \\
\hline Rovesnitsa & 47.50 & 58.10 & 64.34 & 69.00 & 59.74 \\
\hline Turgenevka & 67.20 & 55.77 & 63.45 & 83.14 & 67.39 \\
\hline V2-180 & 77.90 & 60.00 & 78.75 & 89.25 & 76.48 \\
\hline Izmailovsky & 78.92 & 67.75 & 94.55 & 96.25 & 84.37 \\
\hline Rubin & 64.75 & 76.50 & 66.40 & 72.75 & 70.10 \\
\hline Average for media options & $\mathbf{6 6 . 7 2}$ & $\mathbf{6 3 . 9 7}$ & $\mathbf{7 3 . 6 5}$ & $\mathbf{7 8 . 8 1}$ & $\mathbf{7 0 . 7 9}$ \\
\hline \multicolumn{1}{|c|}{ LSD $_{05}$} & 2.33 & 2.47 & 4.15 & 3.39 & 2.56 \\
\hline Average for medium & \multicolumn{6}{|c|}{} & & $\mathbf{7 6 . 2 3}$ & $\mathbf{7 0 . 7 9}$ \\
\hline
\end{tabular}

In general, it should be noted that the studied genotypes reacted differently to the studied variants of nutrient media. The viability of the explants of some of them differed significantly depending on the composition of the culture medium (such as, for example, in the varieties Podarok Uchitelyam, Rovesnitsa, Turgenevka, clonal rootstocks Rubin and V2-180). The viability of other genotypes explants did not differ significantly (Livenskaya 
variety) or slightly differ (Rubin clonal rootstock) on different variants of nutrient media. Thus, the manifestation of variety specificity in relation to the composition of culture media was revealed.

It was also found that explants of clonal cherry rootstocks had a higher viability compared to the viability of cherry varieties explants at the first stage of clonal micropropagation. Among the clonal rootstocks, the Izmailovsky rootstock was the best viable $(84.37 \%)$, and among the varieties - the Podarok Uchitelyam variety $(72.05 \%)$.

The intensity of development of micro-shoots of the studied cherry genotypes at the stage of introduction into the crop in vitro was higher in the experimental medium: the length of micro-shoots was $6.75 \mathrm{~mm}$, compared to $4.54 \mathrm{~mm}$ in the MS medium (Table 5). Most of the studied forms showed the best results on an experimental nutrient medium with the following concentration of growth regulators: GA $0.5 \mathrm{mg} / 1,6-\mathrm{BAP} 1.5 \mathrm{mg} / \mathrm{l}$, IBA 1 $\mathrm{mg} / \mathrm{l}$. The exception was the Podarok Uchitelyam variety and the Izmailovsky clone rootstock with the best results on the Experimental medium with a content of GA $0.5 \mathrm{mg} / \mathrm{l}$, 6-BAP $1.5 \mathrm{mg} / 1$, IBA $0.5 \mathrm{mg} / 1$. In terms of the micro-plant length at this stage, there was no significant difference: from $5.19 \mathrm{~mm}$ to $6.16 \mathrm{~mm}$.

Table 5. Dependence of the intensity of development of clonal rootstocks and cherry varieties explants at the stage of introduction into the crop in vitro on the composition of the nutrient medium and genotype, on average for 2017-2020.

\begin{tabular}{|c|c|c|c|c|c|}
\hline \multirow{2}{*}{$\begin{array}{c}\text { Name } \\
\text { of genotype }\end{array}$} & \multicolumn{5}{|c|}{ Micro-plants length, mm } \\
\hline & MS-I & MS-II & EX-I & EX-II & Average for genotype \\
\hline Livenskaya & 4.45 & 4.05 & 6.83 & 5.79 & 5.28 \\
\hline Podarok Uchitelyam & 3.89 & 5.34 & 6.83 & 8.04 & 6.03 \\
\hline Rovesnitsa & 4.86 & 5.48 & 7.30 & 6.40 & 6.01 \\
\hline Turgenevka & 4.05 & 4.15 & 6.71 & 6.56 & 5.37 \\
\hline V2-180 & 4.80 & 3.38 & 7.03 & 5.54 & 5.19 \\
\hline Izmailovsky & 3.75 & 6.05 & 5.45 & 6.75 & 5.50 \\
\hline Rubin & 4.45 & 4.85 & 7.82 & 7.50 & 6.16 \\
\hline $\begin{array}{c}\begin{array}{c}\text { Average for media } \\
\text { options }\end{array} \\
\end{array}$ & 4.32 & 4.76 & 6.85 & 6.65 & 5.65 \\
\hline $\mathrm{LSD}_{05}$ & 0.33 & 0.46 & 0.63 & 0.42 & 0.29 \\
\hline Average for medium & \multicolumn{2}{|c|}{4.54} & \multicolumn{2}{|c|}{6.75} & 5.65 \\
\hline
\end{tabular}

It was found that when studying the viability and development intensity of clonal rootstocks and cherry varieties explants, the Experimental medium with the proposed variants of growth regulators content is the best medium at the first stage of clonal microreproduction for the studied genotypes.

When studying the effect of the organo-mineral composition and growth regulators of the culture medium on the effectiveness of the second stage of clonal micropropagation of cherry genotypes, it was found that the viability of cultivated explants of the studied cherry genotypes was significantly higher in the Experimental medium (on average 57.90\%) compared to the MS medium (on average 39.45\%) (Table 6). Most of them showed better viability on the Experimental medium option with a concentration of GA $0.5 \mathrm{mg} / \mathrm{l}, 6$-BAP $1.5 \mathrm{mg} / \mathrm{l}$, IBA $0.5 \mathrm{mg} / \mathrm{l}$ (average viability $-60.81 \%$ ). 
Table 6. Viability of cherry varieties and clonal rootstocks explants in the crop in vitro at the stage of proliferation, depending on the composition of the nutrient medium and genotype, on average for

2017-2020., \%

\begin{tabular}{|c|c|c|c|c|c|}
\hline \multirow[b]{2}{*}{$\begin{array}{c}\text { Name } \\
\text { of genotype }\end{array}$} & \multicolumn{5}{|c|}{ Explant viability, \% } \\
\hline & MS-I & MS-II & EX-I & EX-II & $\begin{array}{l}\text { On average } \\
\text { for genotype }\end{array}$ \\
\hline Livenskaya & 40.38 & 38.33 & 54.63 & 62.83 & 49.04 \\
\hline Podarok Uchitelyam & 47.78 & 60.27 & 72.70 & 72.43 & 63.30 \\
\hline Rovesnitsa & 29.26 & 27.90 & 34.96 & 55.73 & 36.96 \\
\hline Turgenevka & 47.04 & 42.11 & 48.08 & 71.85 & 52.27 \\
\hline V2-180 & 25.14 & 30.37 & 55.44 & 43.10 & 38.51 \\
\hline Izmailovsky & 56.90 & 39.93 & 63.46 & 66.48 & 56.69 \\
\hline Rubin & 25.19 & 41.67 & 55.65 & 53.24 & 43.94 \\
\hline $\begin{array}{c}\text { Average for media } \\
\text { options }\end{array}$ & 38.81 & 40.08 & 54.99 & 60.81 & 48.67 \\
\hline $\mathrm{LSD}_{05}$ & 3.36 & 3.66 & 4.12 & 3.53 & 3.42 \\
\hline Average for medium & \multicolumn{2}{|c|}{39.45} & \multicolumn{2}{|c|}{57.90} & 48.67 \\
\hline
\end{tabular}

Among the clonal rootstocks, the Izmailovsky rootstock showed greater viability at proliferation stage $(56.69 \%)$, and among the varieties - the Podarok Uchitelyam variety $(63.30 \%)$.

The development intensity of micro-plants of all cultivated cherry genotypes at proliferation stage was also significantly higher in the Experimental medium (on average $11.73 \mathrm{~mm}$ ) compared to the MS medium (on average $8.59 \mathrm{~mm}$ ) (Table 7). All the studied varieties and rootstocks, except for the Turgenevka variety, showed a high development intensity of micro-shoots on the Experimental medium with a content of GA $0.5 \mathrm{mg} / \mathrm{l}, 6$ BAP $1.5 \mathrm{mg} / \mathrm{l}$, IBA $0.5 \mathrm{mg} / \mathrm{l}$ (on average $12.34 \mathrm{~mm}$ ).

It was found that at the proliferation stage, on average, the intensity of the development of most cherry varieties micro-shoots was higher than the intensity of the development of clonal rootstocks micro-shoots. Among the varieties on all the tested media variants, the Podarok Uchitelyam variety showed a high intensity of micro-shoots development (on average, $13.00 \mathrm{~mm}$ ). Among the clonal rootstocks, it was not possible to single out the best one for this indicator.

Table 7. Dependence of development intensity of explants of clonal rootstocks and cherry varieties in the crop in vitro at proliferation stage on the genotype and composition of the nutrient medium, on average for $2017-2020, \mathrm{~mm}$.

\begin{tabular}{|c|c|c|c|c|c|}
\hline \multirow{2}{*}{$\begin{array}{c}\text { Name } \\
\text { of genotype }\end{array}$} & \multicolumn{5}{|c|}{ Micro-plants length, mm } \\
\cline { 2 - 6 } & MS-I & MS-II & EX-I & EX-II & Average for genotype \\
\hline Livenskaya & 8.58 & 8.05 & 11.58 & 12.77 & 10.25 \\
\hline Podarok Uchitelyam & 13.67 & 12.34 & 12.00 & 14.00 & 13.00 \\
\hline Rovesnitsa & 6.90 & 13.90 & 14.47 & 15.50 & 12.69 \\
\hline Turgenevka & 7.56 & 6.10 & 9.45 & 9.00 & 8.03 \\
\hline V2-180 & 6.44 & 6.85 & 10.46 & 11.58 & 8.83 \\
\hline Izmailovsky & 7.35 & 8.52 & 10.11 & 10.94 & 9.23 \\
\hline Rubin & 6.10 & 7.85 & 9.77 & 12.58 & 9.08 \\
\hline & & & & & 10.16 \\
\hline Average for media options & $\mathbf{8 . 0 9}$ & $\mathbf{9 . 0 9}$ & $\mathbf{1 1 . 1 2}$ & $\mathbf{1 2 . 3 4}$ & $\mathbf{1 0 . 9 8}$ \\
\hline \multicolumn{7}{|c|}{$\mathbf{8 S D}$} \\
\hline
\end{tabular}


The composition of the nutrient media influenced the multiplication coefficient of micro-plants of cultivated common cherry genotypes. Best of all, the clonal rootstocks explants were propagated on the Experimental medium with a concentration of GA 0.5 $\mathrm{mg} / \mathrm{l}$, 6-BAP $1.5 \mathrm{mg} / \mathrm{l}$, IBA $1 \mathrm{mg} / \mathrm{l}$ : for the rootstock V2-180, Rubin and Izmailovsky, the multiplication coefficient on it was 3.15; 3.15 and 2.95 pcs/explant, respectively (Table 8 ).

Table 8. Dependence of the multiplication coefficient of clonal rootstocks and cherry varieties explants in the crop in vitro at proliferation stage on the composition of the nutrient medium and genotype, on average for 2017-2020.

\begin{tabular}{|c|c|c|c|c|c|}
\hline \multirow{2}{*}{$\begin{array}{c}\text { Name } \\
\text { of genotype }\end{array}$} & \multicolumn{5}{c|}{ Multiplication coefficient, pcs/explant } \\
\cline { 2 - 6 } & MS-I & MS-II & EX-I & EX-II & On average for genotype \\
\hline Livenskaya & 1.93 & 3.00 & 2.30 & 2.50 & 2.43 \\
\hline Podarok Uchitelyam & 2.00 & 2.50 & 2.70 & 2.90 & 2.53 \\
\hline Rovesnitsa & 2.40 & 2.50 & 2.50 & 2.30 & 2.40 \\
\hline Turgenevka & 2.50 & 3.00 & 2.60 & 2.70 & 2.70 \\
\hline V2-180 & 2.55 & 1.85 & 3.15 & 2.85 & 2.60 \\
\hline Izmailovsky & 2.35 & 2.55 & 3.15 & 3.05 & 2.78 \\
\hline Rubin & 1.95 & 1.95 & 2.95 & 2.35 & 2.30 \\
\hline $\begin{array}{c}\text { Average for media } \\
\text { options }\end{array}$ & $\mathbf{2 . 2 4}$ & $\mathbf{2 . 4 8}$ & $\mathbf{2 . 7 6}$ & $\mathbf{2 . 6 6}$ & $\mathbf{2 . 5 3}$ \\
\hline \begin{tabular}{c} 
Average for medium \\
\hline
\end{tabular} & $\mathbf{2 . 3 6}$ & $\mathbf{2 . 7 1}$ & $\mathbf{2 . 5 3}$ \\
\hline
\end{tabular}

For the varieties Turgenevka and Livenskaya, the maximum multiplication coefficient of micro-plants was found on the medium MS-II (3.00 pcs./explant); for the variety Rovesnitsa - on the media MS-II and EX-I (2.50 pcs./explant); for the variety Podarok Uchitelyam - on EX-II (2.90 pcs./explant). The average multiplication coefficient of cherry genotype explants in the crop in vitro at proliferation stage varied slightly: from 2.40 pcs./explant in the Rovesnitsa variety to 2.70 pcs./explant in the Turgenevka variety.

Thus, summarizing the results obtained on the study of the influence of nutrient media composition on the efficiency of proliferation stage of cultivated cherry genotypes, we found that the best medium for cultivating micro-plants of cherry varieties and clonal rootstocks is the Experimental medium. The best viability and intensity of development of micro-plants of the genotypes cultivated on it can be achieved with the addition of GA 0.5 $\mathrm{mg} / \mathrm{l}$, 6-BAP $1.5 \mathrm{mg} / \mathrm{l}$, IBA $0.5 \mathrm{mg} / \mathrm{l}$, and the best multiplication coefficient - with the addition of GA $0.5 \mathrm{mg} / 1,6$-BAP $1.5 \mathrm{mg} / 1$, IBA $1 \mathrm{mg} / 1$.

\section{Conclusions}

It is established that the dates of plant explants introduction into the crop, their genotype and the composition of the culture medium are effectiveness factors of the technology of clonal micro-propagation of cherry clonal rootstocks and varieties at the initial stages of cultivation.

The best calendar dates for the autumn-winter-spring period for the introduction of common cherry varieties and clonal rootstocks explants into the crop in vitro are February and March, corresponding to the period when the vegetative buds of annual shoots of the original forms are in the state of induced dormancy.

The optimal medium at the first stage of clonal micro-propagation for the studied genotypes is an Experimental medium with the following variants of growth regulators content: GA $0.5 \mathrm{mg} / 1,6-\mathrm{BAP} 1.5 \mathrm{mg} / \mathrm{l}$, IBA $1 \mathrm{mg} / 1$ and GA $0.5 \mathrm{mg} / 1$, 6-BAP $1.5 \mathrm{mg} / \mathrm{l}, \mathrm{IBA}$ $0.5 \mathrm{mg} / \mathrm{l}$. 
At the second stage of clonal micropropagation, the best medium for the organo-mineral composition for the cultivated genotypes is the Experimental medium. The best viability and intensity of development of micro-plants of the cherry varieties and clonal rootstocks cultivated on it can be achieved with the addition of GA $0.5 \mathrm{mg} / 1,6-\mathrm{BAP} 1.5 \mathrm{mg} / \mathrm{l}$, IBA 0.5 $\mathrm{mg} / \mathrm{l}$, and the best multiplication coefficient - with the addition of GA $0.5 \mathrm{mg} / 1,6$-BAP 1.5 $\mathrm{mg} / \mathrm{l}$, IBA $1 \mathrm{mg} / \mathrm{l}$.

The best reproductive potential in the crop in vitro at the initial stages of clonal micropropagation among all the studied common cherry genotypes was shown by the Podarok Uchitelyam variety and the Izmailovsky clonal rootstock.

\section{References}

1. A.F. Kolesnikova, Improving cherry range of varieties based on clone selection, 183 (2010)

2. E.N. Dzhigadlo, Improvement of breeding methods, creation of cherry and black cherry varieties, their rootstocks with ecological adaptation to the conditions of the Central region of Russia, 268 (VNIISPK, 2009)

3. V.A. Vysotsky, Doctor of Agricultural Sciences, 44 (1998)

4. A.E. Shelifost, S.S. Kostyshin, R.A. Volkov, Biotechnology, 5, 19 (1993)

5. V.G. Lebedev, A.B. Azarova, M.S. Arkaev, Biotechnology, 2(33), 76 (2017)

6. O.I. Molkanova, Yu.N. Gorbunov, I.V. Shirnina, D.A. Egorova, Botanical Magazine, 6(105), 610 (2020)

7. O.V. Matushkina, I.N. Pronina, Fruit and berry Growing of Russia, 224 (2008)

8. E.N. Dzhigadlo. M.I. Dzhigadlo, A.A. Gulyaeva, I.N. Ryapolova, international scientific method. Conf, 152 (VNIISPK Publishing House, 2005)

9. S.L. Rastorguev, Culture of isolated tissues and organs in fruit plants breeding, 170 (MichSAU Publishing House, 2009)

10. E.L. Kharkhardina, I.E. Fedotova, O.V. Ostrikova, Present and future training of students and university students in the field of natural sciences, 406 (2016)

11. I.E. Fedotova, O.V. Ostrikova, E.L. Kharkhardina, Fruit and berry growing of Russia: Coll. of sc. works of the SSI VSTISP Russian Agricultural Academy, 2, 295 (2017)

12. E.N. Dzhigadlo, M.I. Dzhigadlo, Improvement of the assortment, and progressive methods of fruit and berry crops cultivation, 52 (Priok. pub. House, 1988).

13. V.I. Demenko, Methodological guidelines for practic. classes in fruit growing, 35 (MAA, 1997)

14. E.N. Dzhigadlo, Methodological recommendations on the use of biotechnological methods in work with fruit, berry and ornamental crops, 50 (2005)

15. B.A. Dospekhov, Methodology of field experience, 351 (Agropromizdat, 1985) 